\title{
Evaluation of Antioxidant and Anti-amylase Activities of Sukhasarak Churna, an Ayurvedic Formulation
}

\author{
Ashok Kumar B.S ${ }^{1 *}$, Lakshman, $\mathrm{K}^{2}$, Nandeesh, $\mathbf{R}^{3}$ and Gopi Setty Saran ${ }^{1}$ \\ 1Department of Pharmacognosy, Sri K.V. College of Pharmacy, Chickballapur, Karnataka, India \\ ${ }^{2}$ Department of Pharmacognosy, PES College of Pharmacy, Bangalore, Karnataka, India \\ ${ }^{3}$ Department of Pharmacognosy, Sree Sidhaganga College of Pharmacy, Tumkur, Karnataka, India.
}

\begin{tabular}{|c|c|}
\hline Abstract & Article Information \\
\hline $\begin{array}{l}\text { Sukhasarak churna, an ayurvedic formulation, traditionally used as laxative, digestive, blood } \\
\text { purifier and liver disorder. The main aim of the study is to carryout antioxidant and anti- } \\
\text { amylase activities aqueous extract of Sukhasarak churna. Aqueous extract of Sukhasarak } \\
\text { churna was screening for antioxidant activity by DPPH (1,1-diphenyl-2-picrylhydrazyl) radical } \\
\text { scavenging assay, nitric oxide scavenging assay and ferric reducing power and anti- } \\
\text { amylase activity by dinitrosalicylic acid method (DNSA). Sukhasarak churna shows potent } \\
\left.\text { antioxidant activity: DPPH scavenging (IC } \mathrm{C}_{50} \text { value } 521.3 \pm 2.5\right) \text { and Nitric oxide radical } \\
\text { scavenging (IC value } 490.76 \pm 1.8 \text { ) and anti-amylase }\left(\mathrm{IC}_{50} \text { value } 570.95 \pm 1.2\right) \text { by DNSA } \\
\text { method. The studies are of great significance as the demand for herbal products as } \\
\text { antioxidants and alpha amylase inhibitor is increasing constantly. } \\
\text { Copyright@2015 STAR Journal, Wollega University. All Rights Reserved. }\end{array}$ & $\begin{array}{l}\text { Article History: } \\
\text { Received : 12-02-2015 } \\
\text { Revised : 28-05-2015 } \\
\text { Accepted : 03-06-2015 } \\
\text { Keywords: } \\
\text { Sukhasarak Churna } \\
\text { Antioxidant activity } \\
\text { Anti-Amylase activity } \\
{ }^{*} \text { Corresponding Author: } \\
\text { Ashok Kumar, B.S } \\
\text { E-mail: } \\
\text { ashok4vani@gmail.com }\end{array}$ \\
\hline
\end{tabular}

\section{INTRODUCTION}

The use of Ayurvedic formulations has led to the sudden increase in the number of Ayurvedic drug manufactures due to the toxicity and side effects of allopathic medicines. Sukhasarak churna, an ayurvedic formulation, contains sonamukhi (Cassia angustifolia), ginger (Zingiber officinale), Haritaki (Emblica officinalis), Vidanga (Emblia ribes), Amla (Phyllanthus emblica) ajowan (Trachyspermum ammi) and liquorice (Glycyrrhiza glabra). Sukhasarak churna traditionally used as laxative, digestive, blood purifier and liver disorder.

Antioxidants are the substance that reduce oxidation and so counteract the reactive species. Reactive oxygen species (ROS) are major free radicals generated in many redox processes, which may induce oxidative damage to biomolecules, including carbohydrates, proteins, lipids, and DNA. Reactive oxygen species affect living cells, which mediate the pathogenesis of many chronic diseases, such as atherosclerosis, Parkinson's disease, Alzheimer's disease, stroke, arthritis, chronic inflammatory diseases, cancers, and other degenerative diseases (Mc Dermott, 2000). The action of ROS is opposed by a balanced system of antioxidant compounds produced in vivo (Halliwell and Gutteridge,1998). Endogenous antioxidants are insufficient, and dietary antioxidants are required to countermeasure excess ROS (Lim and Murtijaya, 2007).

Amylase inhibitors are also known as starch blockers because they contain substances that prevent dietary starches from being absorbed by the body. Starches are complex carbohydrates that cannot be absorbed unless they are first broken down by the digestive enzyme amylase and other secondary enzymes (Arnubio Valenica et al., 2000).

More recent research utilizing purified amylase inhibitors have demonstrated that these antinutrients can rapidly inactivate amylase in human intestinal lumen in a dose dependent manner and post prandial rises in glucose and insulin (Marshall and Lauda, 1975). Essentially, it allows the carbohydrates to pass through the system possibly with less caloric intake.

Although the acute effects of $\alpha$-amylase inhibitors may appear to have therapeutic benefit in patients suffering from diabetes mellitus, obesity and other diseases of insulin resistance, chronic administration in animal models has been shown to induce adverse effects including deleterious histological changes to the pancreas. The main of this study is to evaluate antioxidant and $\alpha$ Amylase inhibition activities of Sukhasarak churna.

\section{MATERIALS AND METHODS}

Preparation of Churna and Extraction

Sukhasarak churna contents: Cassia angustifolia-40 gm, Zingiber officinale-20 gm, Emblica officinalis-20 gm, Emblia ribes -20 gm, Phyllanthus emblica-100 gm, Trachyspermum ammi $-20 \mathrm{gm}$ and Glycyrrhiza glabra-10 gm. were cleaned and dried material was made to fine 
powder and passed through sieve no.100 and mixed geometrically and extracted with water and dried.

\section{Antioxidant Activity \\ DPPH Radical Scavenging Activity}

The DPPH assay measured hydrogen atom donating activity and hence provided an evaluation of antioxidant activity due to free radical scavenging. DPPH, a purplecolored stable free radical, was reduced into the yellowcolored diphenylpicryl hydrazine; the color intensity of the reaction mixture was measured spectrophotometrically at $510 \mathrm{~nm}$ (Layer et al., 1986). Briefly, $2.8 \mathrm{ml}$ of DPPH (24 $\mathrm{mg}$ in $100 \mathrm{ml}$ of ethanol) solution was added to various concentration of aqueous extract of leaves of Sukhasarak churna and incubated at $25{ }^{\circ} \mathrm{C}$ for $20 \mathrm{~min}$. After incubation, the absorbance of the reaction mixture was read at $510 \mathrm{~nm}$. Similarly, a control reaction was carried out without the Sukhasarak churna. The DPPH radicalscavenging activity was expressed as percentage inhibition and calculated according to the following equation:

$$
\% \text { of Inhibition }=\left(A_{0}-A_{1}\right) / A_{0} \times 100
$$

Where $A_{0}$ was the absorbance of the control (without extract) and $A_{1}$ was the absorbance in the presence of the extract.

\section{Nitric Oxide Scavenging Activity}

In nitric oxide (NO) scavenging activity, the nitric oxide was liberated from sodium nitroprusside at physiological $\mathrm{pH}$. This nitric oxide gets converted to nitrous acid and further forms nitrite ions $\left(\mathrm{NO}^{2-}\right)$, which may be quantified by the Griess reagent. 20 Sodium nitroprusside $(10 \mathrm{mM}$, $50 \mu \mathrm{l})$ in phosphate buffer saline was incubated with $50 \mu \mathrm{l}$ of various concentrations of aqueous extract of leaves of Sukhasarak churna at room temperature for $15 \mathrm{~min}$. After incubation, $125 \mu \mathrm{l}$ of Griess reagent was added and incubated for $10 \mathrm{~min}$ at room temperature. The color developed was measured at $546 \mathrm{~nm}$ (Vani et al., 1997). The nitric oxide radicals scavenging activity was calculated according to the following equation:

$\%$ of Inhibition $=\left(A_{0}-A_{1}\right) / A_{0} \times 100$

\section{Ferric Reducing Power}

The ferric reducing power of the aqueous extract of Sukhasarak churna was determined by using potassium ferricyanide-ferric chloride method (Sreejayan and Rao, 1997). Different concentrations $(100-1000 \mu \mathrm{g} / \mathrm{ml})$ of extracts were added to $2.5 \mathrm{ml} 0.2 \mathrm{M}$ phosphate buffer $(\mathrm{pH}$ 6.6 ) and $2.5 \mathrm{ml}$ potassium ferricyanide (1\%). The mixtures were incubated at $50^{\circ} \mathrm{C}$ for $20 \mathrm{~min}$, after which $2.5 \mathrm{ml}$ trichloroacetic acid (10\%) was added. Two and one half milliliters of the mixture was taken and mixed with $2.5 \mathrm{ml}$ water and $0.5 \mathrm{ml} 1 \% \mathrm{FeCl}_{3}$. The absorbance at $700 \mathrm{~nm}$ was measured after allowing the solution to stand for 30 min. A graph of absorbance vs. extract concentration was plotted to observe the reducing power.

\section{In Vitro Alpha Amylase Inhibition Assay}

The inhibition assay was performed according to Miller (1986) using DNS (3, 5-dinitrosalicylic acid method) method. Aqueous extract of leaves of Sukhasarak churna of varied concentrations in $500 \mu \mathrm{l}$ were added to $500 \mu \mathrm{L}$ of $0.02 \mathrm{M}$ sodium phosphate buffer ( $\mathrm{pH} 6.9$ containing $6 \mathrm{mM}$ sodium chloride) containing 0.04 units of alpha amylase solution and were incubated at $37^{\circ} \mathrm{C}$ for $10 \mathrm{~min}$, followed by addition of $500 \mu \mathrm{L}$ of a $1 \%$ starch solution in $0.02 \mathrm{M}$ sodium phosphate buffer $(\mathrm{pH} 6.9)$ all the test tubes. The reaction was stopped with $1.0 \mathrm{ml}$ of 3,5 DNSA reagent. The test tubes were then incubated in a boiling bath water for $5 \mathrm{~min}$, cooled to room temperature. The reaction mixture was then diluted after adding $10 \mathrm{ml}$ distilled water and absorbance was measured at $540 \mathrm{~nm}$. The control samples were also prepared accordingly without any plant extracts and were compared with the test samples containing various concentrations of the plant extracts prepared with different solvents. The results were expressed as \% inhibition calculated using the formula:

$\%$ Inhibition activity $=\frac{\text { Abs (Control) }- \text { Abs (Extract) } \quad X 100}{\text { Abs (Control) }}$

\section{RESULTS}

DPPH, which is a stable free radical with purple color, the intensity was measured at $510 \mathrm{~nm}$ spectrophotometrically to determine $\mathrm{DPPH}$ radical scavenging activity. The aqueous extract of Sukhasarak churna reduced DPPH in to 1,1-diphenyl-2-picryl hydrazine, a colorless compound with $\mathrm{IC}_{50}$ value of $521.31 \pm 2.3 \mu \mathrm{g} / \mathrm{ml}$. Sodium nitroprusside in aqueous solution at physiological $\mathrm{pH}$ spontaneously generates nitric oxide, which interact with oxygen to produce nitrite ions. The aqueous extract of Sukhasarak churna had significantly scavenged the generated nitric oxide radicals with an $\mathrm{IC}_{50}$ value of $490.76 \pm 1.8 \mu \mathrm{g} / \mathrm{ml}$ (Table 1). Figure 1 showed the ferric reducing power of aqueous extract of Sukhasarak churna. Aqueous extract of Sukhasarak churna potent $\alpha$-amylase inhibition and $\mathrm{IC}_{50}$ value was found to be $570.95 \pm 1.2 \mu \mathrm{g} / \mathrm{ml}$

Table 1: Antioxidant activity aqueous extract of Sukhasarak churna ( $\mathrm{IC}_{50}$ Value)

\begin{tabular}{|c|c|c|}
\hline \multirow[b]{2}{*}{ Treatment } & \multicolumn{2}{|c|}{$I_{50}$ Value $(\mu \mathrm{g} / \mathrm{ml})$} \\
\hline & $\begin{array}{l}\text { DPPH Radical } \\
\text { Scavenging } \\
\text { assay }\end{array}$ & $\begin{array}{c}\text { NO Radical } \\
\text { Scavenging } \\
\text { assay }\end{array}$ \\
\hline $\begin{array}{l}\text { Aqueous extract of } \\
\text { Sukhasarak churna }\end{array}$ & $521.31 \pm 2.3$ & $490.76 \pm 1.8$ \\
\hline
\end{tabular}

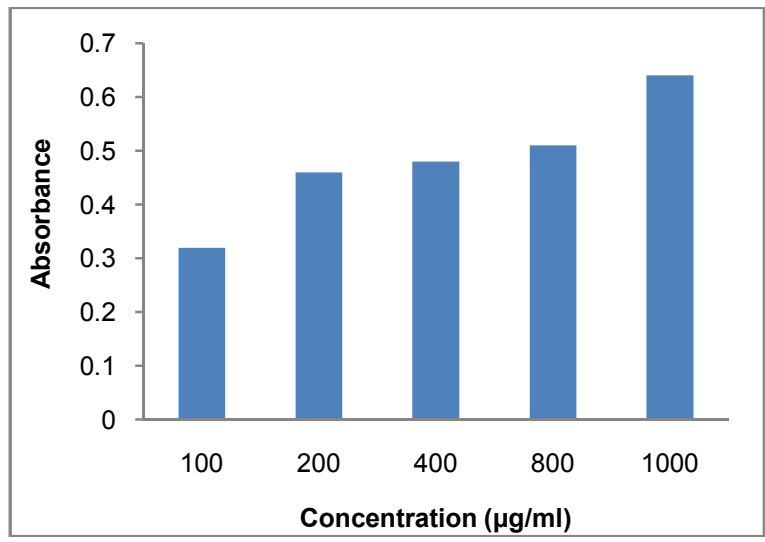

Figure 1: Ferric reducing power assay at various concentration of aqueous extract of Sukhasarak churna

Table 2: In vitro a- Amylase inhibition of Sukhasarak churna

\begin{tabular}{cc}
\hline Treatement & IC $_{50}$ value $(\boldsymbol{\mu g} / \mathrm{ml})$ \\
\hline $\begin{array}{l}\text { Aqueous extract of } \\
\text { Sukhasarak churna }\end{array}$ & $570.95 \pm 1.2$ \\
\hline
\end{tabular}




\section{DISCUSSION}

In living systems, free radicals are constantly generated and they can cause extensive damage to tissue and biomolecules leading to various disease conditions, especially degenerative diseases, and extensive lysis (Oyaizu, 1986). Many synthetic drugs protect against oxidative damage but they have adverse side effects. An alternative solution to the problem is to consume natural antioxidants from food supplements and traditional medicines (Halliwell and Gutteridge, 1998: Yazdanparast and Ardestani, 2007). Recently, many natural antioxidants have been isolated from different plants materials (Yazdanparast et al., 2008; Packer and Ong, 2008).

The effect of antioxidants on DPPH is thought to be due to their hydrogen donating ability (Jovanovic and Simic, 2000). Free radicals are known to be a major factor in biological damages and DPPH has been used to evaluate the free radical scavenging activity of natural antioxidants (Baumann et al., 1979). DPPH; which is a radical itself with a purple color, changes in to a stable compound with a yellow color by reacting with an antioxidant and the extent of the reaction depends on the hydrogen donating ability of the antioxidant. The reduction capability of the DPPH radical is determined by the decrease in its absorbance at $510 \mathrm{~nm}$, induced by antioxidants. In order to evaluate the antioxidant potency through free radical scavenging by the test sample, the change of optical density of DPPH radicals was monitored. Table No.1 shows the decrease in absorbance of DPPH radical due to the scavenging ability of aqueous extract of Sukhasarak churna. $I_{50}$ value of aqueous extract on DPPH radical was $521.31 \pm 2.3$.

It is well known that nitric oxide plays an important role in various inflammatory processes. Sustained levels of production of this radical are directly toxic to tissues and contribute to the vascular collapse associated with septic shock, whereas chronic expression of nitric oxide radical is associated with various carcinoma and inflammatory conditions including juvenile diabetes, multiple sclerosis, arthritis and ulcerative colitis (Zhu et al., 2001). The toxicity of NO increases greatly when it reacts with superoxide radical forming the highly reactive peroxynitrite anion $\left(\mathrm{ONOO}^{-}\right)$. The nitric oxide generated from sodium nitroprusside reacts with oxygen to form nitrite. The extract inhibits nitrite formation by directly competing with oxygen in the reaction with nitric oxide. $\mathrm{IC}_{50}$ value of aqueous extract on nitric oxide scavenging was $490.76 \pm$ 1.8 (Table 1).

Ferric reduction is frequently used as a marker of electron-donating activity and considered as a significant mechanism of phenolic antioxidant action (Hatano et al., 2010). In the ferric reducing antioxidant power (FRAP) assay, the antioxidants in the extracts, if any, would result in reducing $\mathrm{Fe}^{3+}$ to $\mathrm{Fe}^{2+}$ by donating an electron. Amount of this $\mathrm{Fe}^{2+}$ complex can be determined at $700 \mathrm{~nm}$ by evaluating the formation of Perl's Prussian blue. The reductive ability is directly proportional with the absorbance of the APC at $700 \mathrm{~nm}$ (Nabavi et al., 2008). Figure 1 showed the ferric reducing power of aqueous extract of Sukhasarak churna.

Postprandial hyperglycemia is one of the risk factors associated with type 2 diabetes mellitus. Digestion of dietary starch $\alpha$-amylase plays significant role in elevated blood glucose thus inhibition of amylase enzyme is very useful tool in management of hyperglycemia (Ebrahimzadeh et al., 2010). Drugs that inhibit carbohydrate hydrolyzing enzymes have been demonstrated to decrease postprandial hyperglycemia and improve impaired glucose metabolism without promoting insulin secretion of NIDDM patients. Sukhasarak churna showed potent $\alpha$-Amylase inhibition 64.04 and 71.09 at 800 and $1000 \mu \mathrm{g} / \mathrm{ml}$ (Table 2). Natural health products of vegetable origin were clearly indicated as a promising avenue for the prevention of chronic diseases (Kwon et al., 2006).

Sukhasarak churna ingredients posses antidiabetic properties: Cassia angustifolia (Punitha and Manohar, 2006), Zingiber officinale (Yadav et al, 2010), Emblica officinalis (Ali et al., 2008), Ipomoea turpentum (Khan, 2009), Emblica ribes (Shankaraiah et al., 2012), Curcuma longa (Suresh Babu and Srinivas, 1997) and Glycyrrhiza glabra (Koga et al., 2004). Our study supports the antidiabetic activity of Sukhasarak churna.

\section{CONCLUSION}

Sukhasarak Churna, a well known ayurvedic formulation, exhibits antioxidant activity and a-Amylase inhibition activity under in vitro conditions. The studies are of great significance as the demand for herbal products as antioxidants and alpha amylase inhibitor is increasing constantly.

\section{Acknowledgment}

The authors are thankful to Shree K.V. Naveen Kiran, chairman, Sri K.V.College of Pharmacy, Chickballapur, Karnataka (India) for providing facilities to carry out the work successfully.

\section{Conflict of Interest}

Authors declared no conflict of interest

\section{REFERENCES}

McDermott, J.H. (2000). Antioxidant nutrients: current dietary recommendations and research update. Journal of American Pharmceutical Association 40(6):785-799.

Halliwell. B., Gutteridge, J.M.C. (1989). Free Radicals in Biology and Medicine. New York. Oxford University Press; 617-783.

Lim, Y.Y., Murtijaya, J. (2007). Antioxidant properties of Phyllanthus amarus extracts as affected by different drying methods. LWT-Food Science and Technology 40(9):1664-1669

Arnubio Valencia, Alex, E.. Bustillo, Gustavo, E., Ossa, Maarten, J., Chrispeels. (2000). a-Amylases of the coffee berry borer (Hypothenemus hampei) and their inhibition by two plant amylase inhibitors, Insect Biochemistry and Molecular Biology 30:207-213

Marshall, J.J., Lauda, C.M. (1975) Purification and properties of phaseolamin, an inhibitor of alpha-amylase, from the kidney bean, Phaseolus vulgaris. Journal of Biological Chemistry 250:8030-7.

Layer, P., Zinsmeister, A.R., DiMagno, E.P. (1986). Effects of decreasing intraluminal amylase activity on starch digestion and postprandial gastrointestinal function in humans. Gastroenterology 91:4148.

Vani, T., Rajani, M., Sarkar, S., Shishoo, C.J. (1997) Antioxidant properties of the ayurvedic formulation 
Ashok Kumar et alo,

Triphala and its constituents. International Journal of Pharmacognosy 35:313-317.

Sreejayan, M., Rao, M.N. (1997). Nitric oxide scavenging by curcuminoids. Journal of Pharmcy and Pharmacology 49(1):105-107.

Oyaizu, M. (1986). Studies on products of browning reaction: Antioxidative activities of products of browning reaction prepared from glucosamine. Japan Journal of Nutrition 44: $307-315$

Miller, G.L. (1959). Use of Dinitrosalicylic acid reagent for determination of reducing sugar. Analytical Chemistry 31:426-428.

Yazdanparast, R., Ardestani, A. (2007). In vitro antioxidant and free radical scavenging activity of Cyperus rotundus. Journal of Medicinal Food Dec;10(4):667-674.

Yazdanparast, R., Bahramikias, S., Ardestani, A. (2008). Nosturtium officinale reduces oxidative stress and enhances antioxidant capacity in hypercholesterolemic rats. Chemical and Biological Interaction 172:176-184.

Packer, L., Ong, A.S. (1997). Biological oxidants and antioxidants: molecular mechanisms and health effects Champaign, IL: AOCS Press.

Jovanovic, S.V., Simic, M.G. (2000). Antioxidants in nutrition. Annals of the New York Academy of Science 899:326334.

Baumann, J., Wurn, G., Bruchlausen, F.V. (1979). Prostaglandin synthetase inhibiting $\mathrm{O}_{2}$ radical scavenging properties of some flavonoids and related phenolic compounds. Deutsche Pharmakologische Gesellschaft Abstracts of the 20thspring meeting, NaunynSchmiedebergs Abstract No.R27 cited in Achieves of Pharmacology 307:R1-R77.

Zhu, N., Wang, M., We, G.J., Lin, J.K., Yang, C.S., Ho, C.T. (2001). Identification of reaction products of $(-)$ epigallocatechine, (-) epigallocatechin gallate and pyrogallol with DPPB. Food Chemistry 73:345-349.

Hatano, T., Edamatsu, R., Mori, A., Fujita, Y., Yasuhara, E. (1989). Effects of tannins and related polyphenols on superoxide anion radical and on 1,1-diphenyl-2picrylhydrazyl. Chemical and Pharmaceutical Bulletin (Tokyo) 37:2016-2023.

Nabavi, S.M., Ebrahimzadeh, M.A., Nabavi, S.F., Hamidinia, A, Bekhradnia, A.R. (2008). Determination of antioxidant
Sci. Technol. Arts Res. J., April-June 2015, 4(2): 207-210

activity, phenol and flavonoids content of Parrotia persica Mey. Pharmacologyonline 2:560-567.

Ebrahimzadeh, M.A., Nabavi, S.M., Nabavi, S.F., Bahramian, F., Bekhradnia, A.R. (2010) Antioxidant and free radical scavenging activity of $H$. officinalis $L$. var. angustifolius, $V$. odorata, B. hyrcana and C. speciosum. Pakistan Journal of Pharmaceutical Sciences 23:29-34.

Kwon, Y.I., Vattem, D.A., Shetty, K. (2006). Evaluation of clonal herbs of Lamiaceae species for management of diabetes and hypertension. Asia Pacific Journal of Clinical Nutrition 15:107-118.

Punitha, R., Manoharan, S. (2006) Antihyperglycemic and antilipidperoxidative effects of Pongamia pinnata (Linn.) Pierre flowers in alloxan induced diabetic rats. Journal of Ethanopharmacology 105:39-46.

Yadav, J.P., Arya, V., Yadav, S., Panghal, M., Kumar, S., Dhankhar, S. (2010). Cassia occidentalis L.: A review on its ethnobotany, phytochemical, and pharmacological profile. Fitoterapia 81:223-230.

Ali, B.H., Blunden, G., Tanira, M.O., Nemmar, A. (2008) Some phytochemical, pharmacological and toxicological properties of ginger (Zingiber officinale Roscoe): a review of recent research. Food and Chemical Toxicology 46(2):409-20.

Khan, K.H. (2009). Roles of Emblica officinalis in medicine A review. Botany Research International 2:218-228.

Shankaraiah, P., Srinivasa Reddy, C., Ravindra Babu, P. (2012). Comparative antidiabetic activity of methanolic extract of Operculina turpethum stem and root against healthy and streptozotocin induced diabetic rats. International Current Pharmaceutical Journal 1(9): 272278.

Suresh Babu, P., Srinivasan, K. (1997). Hypolipidemic action of curcumin, the active principle of turmeric Curcuma longa in streptozotocin induced diabetic rats. Molecular and Cellular Biochemistry 166:169-175.

Koga, K., Takekoshi, K., Kawashima, S., Taniguchi, M. Murakami, M. (2004). Clove Oil Prevents Glycyrrhizin Gel Formation in Aqueous Solution. Chemical and Pharmaceutical Bulletin 52:1507-1510. 